\title{
Sarah Hardstaff
}

\section{Money and the Gift in the Novels of Mildred Taylor and Cynthia Voigt}

\begin{abstract}
In this article, I present a comparison of the representation of the uses of money and gift economies in two landmark series for young readers from the United States: Mildred Taylor's Logan family novels (1975-2020), centred on an African American family in 1930s Mississippi, and Cynthia Voigt's Tillerman family novels (1981-1989), centred on a white family in 1970s Maryland. Both Taylor and Voigt depict characters navigating the banking system; moreover, both show the ways in which banking is a question not just of economic competence but of social capital and indeed, of social justice. While Taylor presents money as a social tool, used to acquire things of value (rather than having inherent value) and as a means for characters to collaborate or punish one another, Voigt often presents money as a tool for individual self-actualisation. Similarly, in the gift economy, Voigt shows gifts as having economic potency whereas for Taylor these gifts instead act as conduits for social exchange. In both the Logan and Tillerman novels, gifts are used to strengthen social bonds, but can be dangerous too, creating obligations and conditions of repayment that are too onerous for the characters. Often presented as opposites, the differences between monetary and gift economies sometimes seem to collapse in these novels.
\end{abstract}

Keywords: Mildred Taylor, Logan novels, Cynthia Voigt, Tillerman novels, children's literature, economic criticism, banking in fiction, gift economies

(C)2019 Sarah Hardstaff. This is an Open Access article distributed under the terms of the Creative Commons Attribution-Noncommercial 3.0 Unported License (http://creativecommons.org/ licenses/by-nc/3.0/), permitting all non-commercial use, distribution, and reproduction in any medium, provided the original work is properly cited.

Citation: Barnboken - tidskrift för barnlitteraturforskning/Journal of Children's Literature Research, Vol. 42, 2019 http://dx.doi.org/ 10.14811/clr.v42i0.417 
Literature and economics share core structures and themes such as choice, exchange and value: indeed, art and money share the same fundamental paradox of being simultaneously both things and fictional representations of things. In other words, fictional texts reflect, reproduce, influence and question economic and social structures through both their content and form; this is particularly pertinent in children's literature, which due to the age of its audience acts as a form of "economic socialisation" (Van den Bossche 35). Representations of money, as well as alternative economies such as the exchange of gifts, are central to this claimed socialising effect. In this article, I present a comparison of the representation of the uses of money and gift economies in two landmark series for young readers from the United States: Mildred Taylor's Logan family novels (19752020), centred on an African American family in 1930s Mississippi, and Cynthia Voigt's Tillerman family novels (1981-1989), centred on a white family in 1970s Maryland. I aim to demonstrate the multiple uses and meanings of money and gifts in the novels, focusing on their thematic similarities and divergent contexts, highlighting areas of overlap and points of difference.

\section{Money and Gift Economies}

The representation of money in children's literature remains underexplored and under-theorised with notable exceptions in works by Naomi Wood, Sue Saltmarsh and Astrid Van den Bossche. In a chapter titled "Stories of Value: The Nature of Money in Three Classic British Picture Books," Van den Bossche examines the role played by money in three picturebooks, looking at "the pecuniary logic constructed in their fictional worlds [...] highlighting the ideological tensions implicit in the representation of money, commensuration and value" (37). She finds that these depictions show that "money is not only something to be rationally counted and invested, but should also be understood as a social and moral marker ... as a defective indicator of value... and as a divisor of spheres" (37-38). In the Logan and Tillerman novels, money is a concern for both adult and child characters and, as Van den Bossche suggests, conveys multiple social meanings. It is possible to go further and argue that money and the novel form are ideologically indeterminate: "Money and fiction, both representational systems relying on credit, are also often interchangeable ... from Defoe forward, realistic fiction, at least, is always in some sense about money" (Brantlinger 144). As Patrick Brantling- 
er's focus on credit, trust and fictionality suggests, debt is also represented frequently in fiction, including in Taylor's and Voigt's novels.

Running alongside and intersecting with the monetary economy is the gift economy, an arena of much theoretical speculation, in which things are given rather than bartered or bought and sold. In the introduction to Gifts, Markets and Economies of Desire in Virginia Woolf (2008), Kathryn Simpson writes that the gift "resonates with ideals such as altruism, sacrifice and love - a utopian contrast to ... the market" (2). She outlines one way in which the gift functions:

a gift economy can operate in part as an alternative to capitalist exchange by privileging generosity, social bonds and intimacies, and rendering unimportant the purely monetary value of the objects exchanged. Significantly, the expectation or even obligation to reciprocate does not necessarily annul the spirit of the gift and convert it into a mercantile exchange; rather, it fulfils one function of the gift which is to reinforce social bonds. (Simpson 4)

In both the Logan and Tillerman novels, gifts are used to strengthen social bonds, especially those which are discouraged by the oppressive tenets of the formal economy.

Yet gifts can also be more dangerous than Simpson allows here, creating obligations and conditions of repayment that are too onerous for the characters. In his seminal work, The Gift: The Form and Reason for Exchange in Archaic Societies (1954), Marcel Mauss describes how gifts can be used as a way of exerting social control: "To give is to show one's superiority, to be more, to be higher in rank, magister. To accept without giving in return, or without giving more back, is to become client and servant, to become small, to fall lower (minister)" (Mauss 95). In both the Logan and Tillerman books, characters have rational fears of being reduced in this way, due to the race and class oppression they respectively experience. Fears of poverty, violence, financial dependency and losing the family land mean that, in both series, apparent altruism must be scrutinised. Thus, these novels do not draw such a sharp dividing line between the "utopian" gift economy and the market economy as might be expected.

\section{Taylor and Voigt}

Money and gift economies are closely linked to major themes of the Logan and Tillerman novels as delineated in previous criticism. Research on Taylor's novels highlights the links between racism and 
economics (MacCann); the importance of land ownership (Brooks; Martin); difficulties around contracts (Davis); and variations in child and adult agency (McDowell; Hardstaff, "Papa Said"). Meanwhile, research on Voigt's novels often highlights money (Hoffman), economic hardship and labour (Watson; Pearce; Fraustino; Hardstaff, "Economies of Childness"). My previous research highlights the types of agency available to child characters in Taylor's Roll of Thunder, Hear My Cry and the types of labour associated with child characters in Voigt's Homecoming. The present article draws on these insights, bringing together texts by both authors to explore the representation of money and gifts, themselves often associated with different types of agency and labour.

Despite the different historical, racial, regional and social contexts they represent, Taylor's and Voigt's works share not only thematic similarities but also similarities in production, reception and form. Regarding production, some of the texts are published around the same time during the 1980s, an era when American capitalism, particularly finance, reinvented itself under Reagan. In terms of reception, both series contain Newbery Award-winning books - Roll of Thunder, Hear My Cry (1976) and Dicey's Song (1982) - both series are regarded as modern classics of American children's and young adult literature, both have been deployed as classroom texts, and both continue to prompt new critical work. Finally, in terms of form, both series constellate around a main protagonist, yet both too move back and forth in time, with prequels focusing on older generations and sidequels relating the perspectives of friends. Overall, there are five Logan novellas and four full-length novels (with a final novel forthcoming in January 2020), compared with seven full-length Tillerman novels. For this article I highlight examples from the three novel-length works in each series that are narrated by or focalised through the main protagonist: Cassie Logan in Roll of Thunder, Hear My Cry (1976), Let the Circle Be Unbroken (1981) and The Road to Memphis (1990), and Dicey Tillerman in Homecoming (1981), Dicey's Song (1982) and Seventeen Against the Dealer (1989).

In Roll of Thunder, Hear My Cry, set against the backdrop of the Great Depression, narrator Cassie learns about the racism she and her family face in Mississippi. Taylor emphasises the consequences of failed financial speculation and flaws in institutional responses that are specific to the 1930s, as well as the long-term inequalities inherent in the South's cotton economy and sharecropping system. Money is a matter of everyday survival but also a strategic tool, at the heart of acts of resistance carried out by the Logan adults. Let the 
Circle Be Unbroken portrays the aftermath of Roll of Thunder, Hear My $\mathrm{Cry}$ and develops some of its major themes, including those relating to money, gifts and the state of the economy, as the effects of the Depression become more severe. Cassie's brother Stacey runs away with a friend to find work and is missing for much of the novel: they are finally found safe but badly shaken by their experiences working in the sugarcane fields without pay. Finally, The Road to Memphis, set in 1941 and narrated by a now seventeen-year-old Cassie, centres on relationships between the young adults of the community in the context of the United States preparing to go to war. Money and gifts are now exchanged by the young people themselves, rather than being mediated by adults.

The Tillerman novels begin with Homecoming, a story of four siblings - Dicey, James, Maybeth and Sammy - abandoned by their mother (their father had already abandoned the family). Led by the eldest, focalising character Dicey, the children make their way mostly on foot down the east coast of the United States, running out of money, working for money and, eventually, easing their grandmother's concerns about the costs, both emotional and financial, of letting the children live with her in Crisfield, Maryland. Dicey's Song explores the ways in which Dicey and her siblings adapt to their new home with their grandmother, who officially takes on responsibility for the children, a responsibility heightened by the death of their mother. The final novel, Seventeen Against the Dealer, returns to Dicey, after interceding novels focusing on other characters. Now aged twenty-one, Dicey has started her own boat-building business, but her hard work is not enough to compensate for a lack of experience and capital. A drifter called Cisco (implied to be Dicey's estranged father) helps Dicey with her work, but then runs away with her money. Eventually, Dicey is forced to close her business, but the novel closes with her intention to build a boat for herself, a future-facing expression of hope that takes her labour outside the restrictions and injustices of the formal economy.

\section{Money in the Logan and Tillerman Novels: Credit, Contracts and Competence}

Both Taylor and Voigt depict characters navigating the banking system; moreover, both show the ways in which banking is a question not just of economic competence but of social capital and indeed, of social justice. The Logan adults see money as a means of securing their material assets rather than having any value in and of itself. 
Their preference for tangible goods over paper assets can be seen in their distrust of certain methods of storing or transferring money: after he has sold his car, Uncle Hammer brings the money to Cassie's father David in person, claiming not to trust the mail or wire (Taylor, Thunder 188). Paper money is seen as undependable and uncertain. Hammer's contribution is required because the mortgage on the land is recalled by the bank in response to white landowner Harlan Granger's displeasure at the Logan's leadership of a store boycott: the bank "[s]aid our credit's no good anymore" (186). Financial institutions are not only stacked against the Logans' survival and chances of success, financial instruments are weapons that can be used by powerful interests at will. In a monetary system that is inseparable from notions of white supremacy, the Logans can neither trust official creditors, nor are they themselves trusted as debtors. "[M]odern money" writes Brantlinger, "originates in debt and is always a statement of debt, even as it represents wealth" (35). The Logans' already-threatened stability in the form of their land is threatened further by inequalities in access to credit, that is, to wealth itself. The credit system in this case is used to revoke access to opportunities and property rights.

Contract failure is described as a regular feature of Taylor's earlier work, due to her depiction of a "society ... entrenched in the mentality of institutionalized racism" (Davis 190). As Donnarae MacCann writes, Taylor's novels " prove [a] dynamic relationship between economics and race hatred, and upon that foundation, they are then able to offer a view of other social institutions" (116). All monetary transactions are already conducted at a disadvantage, the agency and energy required always involving an extra process - first making the money, then actually getting hold of it. In an argument with his mother at the height of the Great Depression, Stacey expresses his frustration with her reluctance to allow him to get a job: "They [white people] the ones got the money, then they the ones we gonna hafta get it from" (Taylor, Circle 197). Mary's fears are later proven to be accurate when Stacey's boss at the sugarcane plantation refuses to pay him for his ten weeks of hard labour (373). Given the longstanding association between fiction and credit, it is arguable that the attitudes towards money and banking presented in these texts encourage us to eschew official narratives in favour of those that are grounded in material realities, inequalities and experiences like Stacey's.

Adult agency in monetary matters is, by and large, presented as a model to children and young adults: there is no scene featuring protagonist Cassie negotiating with bank managers, and Stacey's at- 
tempts to make money are thwarted by abusive bosses. However, in a later novel, an older Stacey recounts his dealings with Wade Jamison, the sympathetic white lawyer character in the Logan novels, to attain a car on credit: "He said he'd sell it to me on time" (Taylor, Memphis 20). Wade is the only powerful white person who will give the Logans "time," in both the literal and financial sense. Here the young adult characters turn financial credit into a tool for their advantage, countering the historical relationship between financial speculation, cotton production and slavery in the United States (Baptist 270), seen also in the "giant chain of debt-obligations" across the Atlantic slave trade (Graeber, Debt 347), and frequent use of credit secured by mortgages on enslaved people (Beckert 116-117, 221-223). In the purchase of the car on credit, Stacey asserts his humanity and agency by expecting to be treated as an equal rather than an object of speculation himself.

In the Tillerman novels, money is central (cf. Hoffman 181). Yet compared with Taylor's work - where money appears as a social tool of collaboration, objectification and punishment - money in Voigt's novels is closely linked to class status and individual self-actualisation. As with other processes in the novels, money is talked about with precision: "It cost eighty-eight cents" (Voigt, Homecoming 25); "it cost twenty-six dollars to get to Crisfield. Fifty-two dollars there and back" (194). Money is a means by which the Tillerman children demonstrate their competence and imagination, for instance in coming up with different ways for their grandmother Abigail to make money, to maximise her utility - "with a farm, there must be ways of getting money" (378) - selling Christmas trees, keeping chickens, running a vegetable stand, renting out fields, selling butter. James demonstrates that he understands the consequences of not making more money, perhaps better than his grandmother: "With inflation, and if you're on fixed income - you could lose the farm if you can't pay taxes" (379). As with other aspects of the Tillermans' status as children, Abigail asserts her authority over financial matters in the sequel. This too is a difficult adjustment for protagonist Dicey, as seen when Abigail takes her out for lunch: "Dicey ... studied the prices. She found the three cheapest things and then looked to see what they were" (Voigt, Dicey's Song 82). Abigail's subsequent insistence that Dicey choose what she wants rather than what is cheap marks the power struggle between adult and child, but also an induction into new ways of economic thinking and doing for Dicey.

Despite these early signs of interest and ability in the uses and meanings of money, Dicey runs into financial difficulties in Seven- 
teen Against the Dealer. She fails to take out an insurance policy for her business premises, thus suffering considerable losses after being robbed; she also trusts her unofficial assistant Cisco with a cheque to bank, which he cashes before running away. Previously, Dicey has been presented as an unusually competent agent in the informal economy, but in the formal, adult economy, she struggles with the basics - insurance, banking, contracts. Indeed, her would-be boat buyer gives this as an excuse when he walks away from the deal: "no obligation... No contract signed. It was all informal" (Voigt, Seventeen 146). Dicey is portrayed as competent with saving, budgeting and spending as a child in Homecoming, but seems completely unprepared in terms of the financial literacy she needs to thrive as an adult in Seventeen Against the Dealer. Whether this is a matter of a focalising character moving from a naïve belief in her abilities to an awareness of her limits, a reflection of Voigt's refusal to present a straightforward linear narrative of progression (cf. Reid 15) either for the personal maturation of her characters or the growth of the economy, or a comment on the limiting conditions of capitalism even for those who show the most potential and promise, is up for debate. What is known is that in other Crisfield boatyards, knowledge and resources are passed from father to son: Dicey's lack of awareness is in part due to her absent parents and in part due to her class status as a first-generation business owner.

\section{Gifts in the Logan and Tillerman Novels: Debts, Dangers and Promises}

The Tillermans' lack of resources for engaging in the formal economy means that representations of gifts in the novels often coincide with questions of money. Cost and affordability feature largely: for example, Dicey's thoughtfulness for her siblings when Christmas shopping is informed both by the loss of their mother and by the loss of money involved in each transaction (Voigt, Dicey's Song 211). Money and gifts are sometimes counterposed too, as when Dicey refuses a loan of money from boyfriend Jeff (Seventeen 68) but later accepts a gift from him that she does not want (231). Dicey's free indirect discourse reveals her thought process: "When someone offered you something, to help you, you owed them something, you owed them being able to help you out" (217-218). This circular logic recalls the obligations bestowed on the recipient of the gift and perhaps offers some explanation of Dicey's difficulties in the formal economy: although deeply independent-minded, she privileges a relational, 
ethical approach to gifts and debts which precludes success when in competition with the self-interested actors of the market economy.

Sometimes a gift helps to repay an obligation or represents a kind of "paying it forward" from one generation to the next: both aspects can be seen when the circus owner who has helped the children get to Crisfield returns with gifts of bicycles for all of them (Voigt, Homecoming 354-355). As well as providing a means for the children to literally circulate as a mode of transport, these gifts have additional temporal connotations too. Acknowledging the past, the bicycles act as reward for the children's unpaid labour for the circus, and acknowledging the future, they act as recognition of a possible need to take once more to the road; they also grant the Tillermans access to a children's economy of paper routes and the journey to school. Rather than acting to strengthen or weaken social bonds, these gifts not only represent alternative paths and potentialities but also make them materially accessible.

The potentialities represented by the gift can be negative as well as positive. In Taylor's novels, conflicts around gift-giving are most evident in the relationship between the Logan children and their white friend Jeremy Simms. Jeremy gives Stacey a hand-carved wooden flute for Christmas: Stacey initially finds it difficult to draw an equivalence between material and emotional gifts in a scene where he asks his father why Jeremy gave him a gift when he received nothing in return:

‘Papa, how come Jeremy give me this flute? I mean, I didn't give him nothin'.'

'Maybe you did give him something,' said Papa, lighting his pipe.

'No sir, Papa. I ain't never given him nothin'!'

'Not even your friendship?' (Taylor, Thunder 129)

David then warns against friendship between black and white, stating that it cannot be equal. The gift thus acts as a material prompt for an important social lesson.

David's verbal warning is followed in the novel's sequel by a physical demonstration of the dangers of interracial relationships by Uncle Hammer. Jeremy again gives a gift in the form of a photograph of himself, one for Stacey and one for Cassie, giving away the only copies of the only photographs of himself he has ever seen or owned, a gift with no use-value beyond reminding the recipient of the giver (Taylor, Circle 122). Hammer finds Cassie's copy of the photograph and warns her about the risks of sexual exploitation 
by white men and the wrath of the white community if black men approach white women; his lecture culminates in the destruction of the photo: "he crossed to the fireplace and without hesitation threw Jeremy's picture into it" (169). Again an adult intervenes to explain the power imbalance involved in accepting the gift, while Hammer's use of fire to destroy the gift recalls the ways in which fire symbolises white supremacist violence elsewhere in the series, in David's burning of the cotton crop to save TJ's life, the arson attack on the Berry family and Mr Morrison's recollections of his home being burned down. The significance of fire in Taylor's work recalls David Graeber's comments on the multiple meanings of "consumption": "To be consumed by fire, or for that matter consumed with rage ... implies ... being overwhelmed in a way that dissolves away the autonomy of the object or even that destroys the object itself" ("Consumption" 491). The gift is consumed, but not in the sense intended by its giver, and the potential future danger and harm embodied in the gift is thwarted.

The flute and photographs represent Jeremy's offer of friendship. Yet this gift of friendship can neither be freely given nor accepted under the present social conditions; it is, rather, a promise for the future (Mielke 253-254). David and Hammer, in their adult interventions and verbalised opposition to Jeremy's gift-giving, cannot see forward to the sacrifice Jeremy will make when he does become a man in The Road to Memphis, giving up his family and community in order to save a black man's life. In explaining his choice, Jeremy refers in monetary language to his behaviour in failing to prevent an attack on one of the Logans' friends: "Now maybe the debt's paid" (Taylor, Memphis 151). Moreover, this "gift" is later aligned with the original gift of the wooden flute, a recurring phallic symbol in the novels which initially seems to have an uncertain fate: for example, Cassie narrates that she "never saw the flute again" (Thunder 129), she tells a friend that Stacey never plays it nor would he allow Cassie to play it (Circle 115) and she again narrates that Stacey has not played the flute - "at least to my knowledge" (Memphis 42). Yet we also learn that Stacey keeps the flute in "his box of treasured things" (Thunder 130), he tells Jeremy that he has kept it for the best part of ten years (Memphis 42) and, finally, Cassie hears him playing the flute in the woods after Jeremy's departure (Memphis 289). While Stacey takes David's advice and does not use or acknowledge Jeremy's gift publicly, he clearly values the flute, the uncertainty about his feelings reflecting the uncertainty that surrounds the fate of Jeremy and the hope for the future that he represents. 
David couches his lecture to Stacey in the language of cost and risk, as well as drawing on Stacey's comparison of Jeremy and his friend TJ: "Now you could be right 'bout Jeremy making a much better friend than TJ ever will be. The trouble is, down here in Mississippi, it costs too much to find out" (Taylor, Thunder 130). While the relationship between Stacey and Jeremy provides a utopian vision for the future, the relationship between TJ and Jeremy's older brothers can be read as its negative. Their unequal relationship shows how gifts can form the basis of a magister-minister relationship.

In the Logan novels, the gift, like credit, can paradoxically strengthen the position of the giver, and for this reason must often be resisted or accepted with caution. In Voigt's novels, accepting gifts such as the bicycles can afford the child recipients greater agency. By contrast, in Taylor's novels, gifts from outside the family can be dangerous and grant the gifter not just agency but a role as creditor and a sense of ownership over the recipient. Gifts such as Jeremy's photograph prompt destruction through fire. Yet while the flute seems to invite its own symbolic destruction through Stacey's apparent refusal to play it, its recurring significance throughout the series hints at hopes for a more harmonious future.

\section{Conclusion}

In the Logan and Tillerman novels, representations of monetary and gift economies have significant implications for our readings of these novels, providing critical insights that contribute to and expand the existing research on the importance of economics in both series. Depicting money matters as inseparable from racism and social class, Taylor and Voigt complicate narratives of financial competence and the protagonists' progress and agency more generally. Focusing on the different uses and meanings of money and gifts in novels such as these may even be projected to have pedagogical applications, given the parlous state of financial literacy amongst teenagers ("Many Teenagers Struggle"). While Taylor presents money as a social tool, used to acquire things of value (rather than having inherent value) and as a means for characters to collaborate or punish one another, Voigt often presents money as a tool for individual self-actualisation. Similarly, in the gift economy, Voigt shows gifts as having economic potency whereas for Taylor these gifts instead act as conduits for social exchange. In both the Logan and Tillerman novels, gifts are used to strengthen social bonds, but can be dangerous too, creating obligations and conditions of repayment that are too onerous for the characters. 
Often presented as opposites, the differences between monetary and gift economies sometimes seem to collapse in these novels. In the Tillerman books, the division between money and gifts breaks down, as money permits and delimits the selection of thoughtful gifts; furthermore, reflecting on the cost of a gift is positioned as part of this thoughtfulness along with consideration for the recipient's wants. Gifts stand in for payments, and gifts enable the Tillermans to make money. In the Logan books, sharper dividing lines between money and gifts and, in the earlier novels, between adult- and childled participation in the economy, are required when it comes to keeping the children safe in a white supremacist society. Gifts that originate or are implicated in the market economy, such as Jeremy's photographs, are rejected. Yet Stacey's positioning of Jeremy's flute as "treasure" suggests an alternative value system that, though barely vocalised, runs counter to an ethically indebted and oppressive market economy. While the Logan and Tillerman novels convey multiple uses and meanings of money and gifts, it is in expressions of hope that they replicate the logic of credit systems and gift economies alike: the possibility of a more just society is offered to readers like a gift, one that entails both a promise and an obligation.

Biographical information: Sarah Hardstaff recently completed a PhD in Education at the University of Cambridge, specialising in children's literature and the works of Mildred Taylor and Cynthia Voigt. Her research interests include American studies, economic criticism, food studies and functional linguistics. Sarah's most recent publication, co-written with Cambridge colleague Meghanne Flynn, is "Trust Me': Volatile Markets in Twilight and The Hunger Games," which featured in the 2019 special issue of CR: The New Centennial Review on the theme of "Speculative Finance, Speculative Fiction." 


\section{Works Cited}

Baptist, Edward E. The Half Has Never Been Told: Slavery and the Making of American Capitalism. New York, Basic Books, 2014.

Beckert, Sven. Empire of Cotton: A New History of Global Capitalism. London, Allen Books, 2014.

Brantlinger, Patrick. Fictions of State: Culture and Credit in Britain, 1694-1994. Ithaca, Cornell University Press, 1996.

Brooks, Wanda. "An Author as a Counter-Storyteller: Applying Critical Race Theory to a Coretta Scott King Award Book." Children's Literature in Education, vol. 40, no. 1, 2009, pp. 33-45, doi.org/10.1007/ s10583-008-9065-9.

Davis, Pamela M. Shifting Ideology in Mildred D. Taylor's Books. PhD dissertation, Middle Tennessee State University, 2013.

Fraustino, Lisa Rowe. "Abandoning Mothers." Mothers in Children's and Young Adult Literature: From the Eighteenth Century to Postfeminism, edited by Lisa Rowe Fraustino and Karen Coats, Jackson, University Press of Mississippi, 2016, pp. 216-232.

Graeber, David. "Consumption." Current Anthropology, vol. 52, no. 4, 2011, pp. 489-511.

---. Debt: The First 5,000 Years. Brooklyn, Melville, 2011.

Hardstaff, Sarah. "Economies of Childness in Cynthia Voigt's Homecoming." Children's Literature in Education, vol. 50, no. 1, 2019, pp. 47-59, doi.org/10.1007/s10583-018-9375-5.

---. “'Papa Said That One Day I Would Understand': Examining Child Agency and Character Development in Roll of Thunder, Hear My Cry Using Critical Corpus Linguistics." Children's Literature in Education, vol. 46, no. 3, 2015, pp. 226-241, doi.org/10.1007/s10583014-9231-1.

Hoffman, Mary. "Growing Up: A Survey." Children's Literature in Education, vol. 15, no. 3, 1984, pp. 171-185, doi.org/10.1007/ BF01136051.

MacCann, Donnarae. "The Family Chronicles of Mildred D. Taylor and Mary E. Mebane." The All-White World of Children's Books and African American Children's Literature, edited by Osayimwense Osa, Trenton, Africa World Press, 1995, pp. 115-129. 
"Many Teenagers Struggle to Understand Money Matters." OECD, http://www.oecd.org/finance/many-teenagers-struggle-to-understand-money-matters.htm. Accessed 5 November 2019.

Martin, Michelle H. "Let Freedom Ring: Land, Liberty, Literacy, and Lore in Mildred Taylor's Logan Family Novels." The Oxford Handbook of Children's Literature, edited by Julia L. Mickenberg and Lynne Vallone, Oxford, Oxford University Press, 2011, pp. 371-388.

Mauss, Marcel. The Gift: The Form and Reason for Exchange in Archaic Societies. 1954. Translated by W.D. Halls, London, Routledge, 1990.

McDowell, Kelly. "Roll of Thunder, Hear My Cry: A Culturally Specific, Subversive Concept of Child Agency." Children's Literature in Education, vol. 33, no. 3, 2002, pp. 213-225, doi. org/10.1023/A:1019634116385.

Mielke, Tammy L. Literary Constructs of African American Childhood in the 1930s in American Children's Literature. PhD dissertation, University of Worcester, 2006.

Pearce, Elizabeth A. Limitation, Subversion, and Agency: Gendered Spaces in the Works of Margaret Mahy, Cynthia Voigt, and Diana Wynne Jones. PhD dissertation, Illinois State University, 2014.

Reid, Suzanne E. Presenting Cynthia Voigt. New York, Twayne Publishers, 1995.

Saltmarsh, Sue. "Picturing Economic Childhoods: Agency, Inevitability and Social Class in Children's Picture Books." Journal of Early Childhood Literacy, vol. 7, no. 1, 2007, pp. 95-113, doi. org/10.1177/1468798407074838.

Simpson, Kathryn. Gifts, Markets and Economies of Desire in Virginia Woolf. Basingstoke, Palgrave Macmillan, 2008.

Taylor, Mildred D. Let the Circle Be Unbroken. New York, Penguin, 1981.

---. The Road to Memphis. New York, Penguin, 1990.

---. Roll of Thunder, Hear My Cry. New York, Penguin, 1976.

Van den Bossche, Astrid. "Stories of Value: The Nature of Money in Three Classic British Picture Books." The Language of Money and Debt: A Multidisciplinary Approach, edited by Annabelle Mooney and Eva Sifaki, London, Palgrave, 2017, pp. 35-59.

Voigt, Cynthia. Dicey's Song. New York, Atheneum, 1982. 
---. Homecoming. New York, Atheneum, 1981.

---. Seventeen Against the Dealer. New York, Atheneum, 1989.

Watson, Victor. "The Tillerman Series." Coming of Age in Children's Literature: Growth and Maturity in the Work of Philippa Pearce, Cynthia Voigt and Jan Mark. London, Continuum, 2003, pp. 85-124.

Wood, Naomi, J. "Gold Standards and Silver Subversions: Treasure Island and the Romance of Money." Children's Literature, vol. 26, 1998, pp. 61-85. 